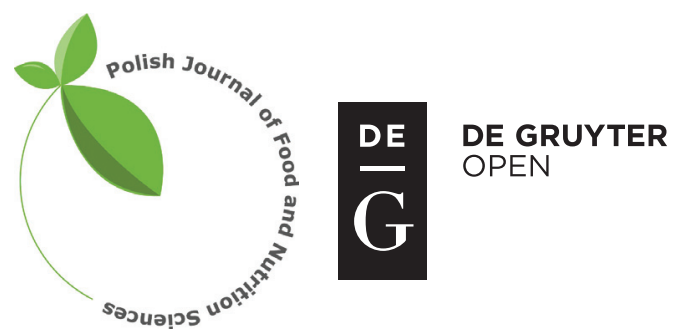

Pol. J. Food Nutr. Sci., 2018, Vol. 68, No. 2, pp. 125-131

DOI: $10.1515 /$ pjfns-2017-0019 http://journal.pan.olsztyn.pl

Original research article

Section: Food Quality and Functionality

\title{
Changes in Enzymatic Activity of Fish and Slaughter Animals Meat after High Pressure Treatment at Subzero Temperatures
}

\author{
Edyta Malinowska-Pańczyk*, Ilona Kotodziejska \\ Department of Food Chemistry, Technology and Biotechnology, Chemical Faculty \\ Gdansk University of Technology, G. Narutowicza 11/12, 80-233 Gdańsk, Poland
}

Key words: high pressure, subzero temperature, protease activity, transglutaminase

The aim of this study was to determine changes in the activity of proteolytic enzymes and transglutaminase of fish and mammal meat after pressurization at subzero temperatures. The activity was measured at the optimal pHs determined for enzymes from particular types of tested meat. It was found that increasing the pressure in the range of 60-193 MPa, did not change significantly the activity of acidic proteases of cod flesh, while the activity of neutral and alkaline proteases decreased drastically. Proteolytic enzymes from salmon flesh were more resistant than those from cod flesh. They maintained or increased (neutral protease) activity after pressurization. The activity of the endogenous enzymes of bovine meat increased with pressure increase, except for acidic proteases, the activity of which was reduced after treatment at $193 \mathrm{MPa}$ to the level similar to unpressurized meat. Endogenous proteases of porcine meat were activated by high-pressure treatment. It has been shown that activity of TGase in unpressurized flesh from cod was 5 times higher than that from unpressurized salmon. Depending on the type of meat, these enzymes were also significantly different in their sensitivity to pressure. The pressure of 60 and $193 \mathrm{MPa}$ led to a complete inactivation of the TGase in cod flesh, while the activity of salmon flesh TGase was decreased only by 15 and $21 \%$, respectively.

\section{INTRODUCTION}

High-pressure technique is one of the most widely used non-thermal methods of food preservation, especially in meat, vegetable, and fruit industries. However, the practical use of this technique should take into account that pressurization causes not only inactivation of spoilage and pathogenic microorganisms in food but also affects most components, which are responsible for product quality [Truong et al., 2015]. It is known that compounds with a low molecular weight, including aromatic substances, dyes or biologically-active molecules such as vitamins, remain unchanged [Tokuşoğlu 2016; Martysiak-Żurowska et al., 2017]. However, pressure induces changes in other food components, such as proteins, including the enzymes, therefore in some cases may limit the usefulness of this method for the preservation or mild food processing. Depending on pressure and temperature, certain enzymes may be activated, while others are inactivated [Truong et al., 2015]. These effects are determined by enzyme properties and origin and by the environmental conditions. Endogenous enzymes are important components of food products affecting their quality [Klomklao et al., 2012]. Some of them cause unfavorable effects, therefore, they should be inactivated during processing and storage of foods. On the other hand, some

\footnotetext{
* Corresponding Author: Tel. +4858 34726 56, Fax: +4858 34726 94;

E-mail: edyta.malinowska-panczyk@pg.gda.pl (E. Malinowska-Pańczyk)
}

enzymes lead to such changes in food which enhance its acceptability by the consumers.

Meat is a source of numerous proteolytic enzymes, which play an important role in tenderization of mammals meat. Limited and selective enzymatic proteolysis during aging leads to changes in the structure of meat, in connective tissue, and some of the myofibrillar proteins. Fragmentation of the myofibrils in mammals meat is positively correlated with its tenderness after heat treatment [Toldra \& Reig, 2015]. In the case of fish flesh, enzymatic degradation of myofibrillar proteins leads to deterioration of fish texture, decreases the shelf-life, and promotes spoilage [Stoknes et al., 2005; Ahmed et al., 2015; Toldra \& Reig, 2015].

Proteolytic enzymes are present in lysosomes and other organelles, in the sarcoplasm and intercellular liquid. They exhibit different sensitivity to high pressure. These enzymes derived from seafood meat are more sensitive to high pressures than their mammalian counterparts [Ashie \& Simpson, 1996]. Pressure in the range of 100-200 MPa, generally increases the activity of cathepsins in mammals meat. This results from the release of enzymes from lysosomal into sarcoplasmic fluids caused by pressure-induced damage in lysosome membrane [Ohmori et al., 1992]. The acid protease (including cathepsin D) of beef meat does not lose its activity after pressurization at $500 \mathrm{MPa}$, while neutral proteases are inactivated already under the pressure of $400 \mathrm{MPa}$ [Ohmori et al., 1991; Jung et al., 2000]. Besides cathepsins also calpains are involved in tenderization of meat. The effect of high pressure on calpain activity depends on sev- 
eral factors: the pressure range, calpastatin activity in these conditions and changes in muscle proteins, i.a. fragmentation of myofibrils. At moderate pressures $(100-150 \mathrm{MPa})$, the activity of calpain in the meat of rabbit and sea bass remains practically unchanged [Cheret et al., 2005; Homma et al., 1995]. It has been found, however, that under these conditions the denaturation of myofibrillar proteins takes place, which increases their susceptibility to enzymatic hydrolysis. At a higher pressure - above $300 \mathrm{MPa}$ - the activity of calpain in sea bass, salmon, and rabbit meat drastically increases [Cheret et al., 2007a; Homma et al., 1995; Lakshmanan et al., 2005].

Another enzyme, which affects the quality of food products, is TGase - glutamine gamma-glutamyltransferase. It is the calcium-dependent enzyme occurring in plants [Serafini-Fracassini \& Del Duca, 2008], fish [Klomklao et al., 2012] and mammals meat [Esposito \& Caputo, 2005] that catalyzes inter- and intra-molecular cross-links between proteins, peptides, and various primary amines [Toldra \& Reig, 2015]. This property of TGase has been proven to be useful in improving functionalities such as gelation and emulsification [DeJong \& Koppelman, 2002]. Endogenous TGase in fish flesh can catalyze the formation of cross-linked myosin heavy chains. This setting reaction of the fish surimi is thought to be important with respect to the rheological properties of fish flesh paste. The sensitivity of TGase to pressure treatment depended on its origin. The activity of TGase from horse mackerel (Trachurus trachurus) decreased by about 35\% after pressurization at $300 \mathrm{MPa}$ and $25^{\circ} \mathrm{C}$ for $15 \mathrm{~min}$ [Montero et al., 2005], while Alaska Pollock TGase was completely resistant to the pressure in the range of $100-300 \mathrm{MPa}$ [Ashie \& Lanier, 1999]. There is no information about the influence of high pressure at subzero temperature on endogenous TGase activity in fish flesh. Our earlier work has shown that moderate pressure at subzero temperature causes denaturation of cod and salmon proteins and induces gelation of washed flesh from these fish [Malinowska-Pańczyk et al., 2014]. Information about the activity of TGase in fish flesh treated by high pressure at subzero temperature is important for applying this technique to design new products from fish flesh.

Therefore, the effect of high pressure on the endogenous enzymes of meat should also be taken into account during determining the high-pressure process parameters. A number of studies have been conducted regarding the high-pressure effect on muscle enzymes but only fragmentary data are reported concerning pressure influence on protease and TGase of fish flesh and mammal meat at subzero temperature without freezing of water.

\section{MATERIALS AND METHODS}

\section{Materials}

Post rigor cod (Gadus morhua) and salmon (Salmo salar) fillets, pork Longissimus dorsi and bovine Biceps femoris muscle were purchased at a local market.

\section{Pressure treatment}

Samples of mammal meat and skinned fish flesh were minced in a meat grinder (mesh diameter $\varphi=3 \mathrm{~mm}$ ), vacuum packed in polyethylene bags and pressurized at 60 ,
111 and $193 \mathrm{MPa}$ at $-5,-10$ and $-20^{\circ} \mathrm{C}$, respectively. Pressurization step lasted 40 min while decompression was performed for $10 \mathrm{~min}$. Under these conditions, the samples were pressure-treated in the unfrozen state. The procedure has been previously described in detail by Malinowska-Pańczyk et al. [2014].

\section{General proteolytic activity}

General proteolytic activity (GPA) in fish flesh and animal meat was estimated according to Erickson et al. [1983] with slight modification. Fifty grams of minced meat were centrifuged at $5000 \times g$ and $4^{\circ} \mathrm{C}$ for $30 \mathrm{~min}$ (MPW 350R centrifuge, MPW Med. Instruments, Poland). The supernatant was collected and used for enzyme assay at $\mathrm{pH} 2.5-9.5$. Two $\mathrm{mL}$ of hemoglobin $(2.5 \%$ solution dissolved in $0.01 \mathrm{~mol} / \mathrm{L} \mathrm{HCl}), 1 \mathrm{~mL}$ of McIlvain buffer ( $\mathrm{pH}$ 2.5, 3.0, 3.2, 4.0, 4.2, 4.6, 5.4, 6.0, 6.2, 6.4, 6.6, 6.8, 7.0, 7.4, 7.6, and 7.8) or Tris- $\mathrm{HCl}$ buffer ( $\mathrm{pH} 8.5$, 9.0, and 9.5), and $0.5 \mathrm{~mL}$ of the supernatant enzyme solution were added to a test tube. Mixtures with cod and salmon samples were incubated at $55^{\circ} \mathrm{C}$ for $3 \mathrm{~h}$. Additional reactions with the supernatant of salmon sample were carried out at $65^{\circ} \mathrm{C}$ and $\mathrm{pH}$ 6.6, 6.8, 7.0, 7.4, 7.8, 8.5, 9.0, and 9.5. These conditions were selected according to Stoknes \& Rustad [1995], as those that ensure the maximum activity of the proteolytic enzymes. In the case of pork and beef meat, the GPA was estimated at $37^{\circ} \mathrm{C}$ for $5 \mathrm{~min}$ and $3 \mathrm{~h}$, respectively. At the end of the incubation period, $6 \mathrm{~mL}$ of $12 \%$ TCA (w/v) were added to each test tube. For the blank sample, the TCA was added to the supernatant solution immediately at the beginning of incubation. Thirty min after TCA addition, the solution was filtered through the filter paper (Filtrak $65 \mathrm{~g} / \mathrm{m}^{2}$, Munktel \& Filtrak GmbH, Barenstein, Germany) and the absorbance was recorded at $280 \mathrm{~nm}$ (Spectrophotometer Spectroquant PHARO300, Merck Millipore, Germany). Proteolytic activity was expressed as an increase in absorbance at $280 \mathrm{~nm}$ (AbU) per $\mathrm{h}$ (or min in the case of pork meat) and mg protein.

The effect of high pressure on the proteolytic activity of the tested meat was estimated at $\mathrm{pH}$ in which the enzyme showed the maximum activity, i.e. 3.0, 7.0 and 8.5 for cod and salmon flesh, 4.2, 6.2 and 7.8 for beef meat, and 4.0, 6.0 and 7.0 for pork meat.

\section{Transglutaminase activity}

The activity of TGase was measured according to Montero et al. [2005] and Worratao et al. [2005]. A solution containing: $20 \mathrm{mmol} / \mathrm{L}$ Tris (2-amino-2-(hydroxymethyl)propane-1,3,diol), $5 \mathrm{mmol} / \mathrm{L}$ EDTA (disodium ethylenediaminetetraacetate), $2 \mathrm{mmol} / \mathrm{L}$ DTT (DL-dithiothreitol), and $10 \mathrm{mmol} / \mathrm{L}$ $\mathrm{NaCl}$ ( $\mathrm{pH} 7.5$ ) was added to minced cod and salmon flesh $(1: 2 \mathrm{w} / \mathrm{v})$ and the sample was homogenized at 10,000 rpm for 2 min (Heidolph Silent Crusher, Heidolph Instruments GmbH, Germany). The homogenate was centrifuged at $9000 \times g$ and $4^{\circ} \mathrm{C}$ for $20 \mathrm{~min}$. Five hundred $\mu \mathrm{L}$ of the supernatant were mixed with $200 \mu \mathrm{L}$ of $1 \mathrm{~mol} / \mathrm{L}$ TAE buffer (pH 6.0), $300 \mu \mathrm{L}$ of $0.1 \mathrm{~mol} / \mathrm{L}$ carbobenzyloxy L-glutaminylglycine, $50 \mu \mathrm{L}$ of $\mathrm{CaCl}_{2}$, and $50 \mu \mathrm{L}$ of $2 \mathrm{~mol} / \mathrm{L}$ hydroxylamine. The samples were incubated at $37^{\circ} \mathrm{C}$ for $10 \mathrm{~min}$ and $1 \mathrm{~mL}$ of $12 \%$ TCA was then added. The mixture was centrifuged at $4000 \times g$ for $15 \mathrm{~min}$ at room temperature and absorbance of the supernatant was 
measured at $525 \mathrm{~nm}$. TGase activity was calculated based on the calibration curve with L-5-N-hydroxyglutamine (Sigma-Aldrich, cat. no. G2253) used as a standard. The amount of enzyme catalyzing the formation of $1 \mu \mathrm{mol} / \mathrm{L} \mathrm{L}-5-\mathrm{N}$-hydroxyglutamine within 1 min was assumed as a unit of activity.

\section{Protein assay}

The Biuret method was used to determinate protein concentration in meat juices and the supernatant obtained during TGase activity determination. Bovine serum albumin was used as a standard.

\section{Statistical analysis}

The data presented in figures and table are average values of at least three replications with standard deviation. The analysis of variance (one-way procedure) was performed to evaluate differences between treatments using the Statistica ver. 8.0 software [StatSoft Inc., USA].

\section{RESULTS AND DISCUSSION}

\section{Effect of pH on the activity of proteolytic enzymes of meat}

Optimal $\mathrm{pH}$ at which the endogenous proteolytic meat enzymes show the maximum activity may vary between species and even within one species [Wasson, 1992]. Thus at the first

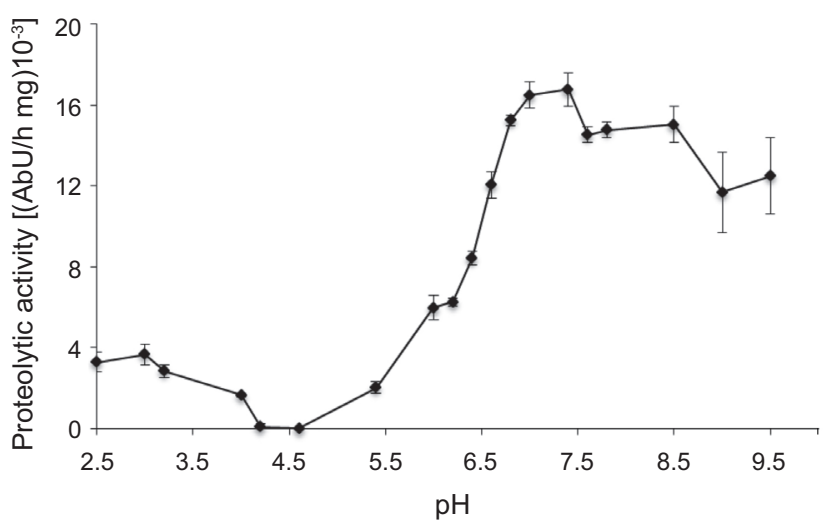

FIGURE 1. Effect of $\mathrm{pH}$ on the general proteolytic activity of cod flesh.

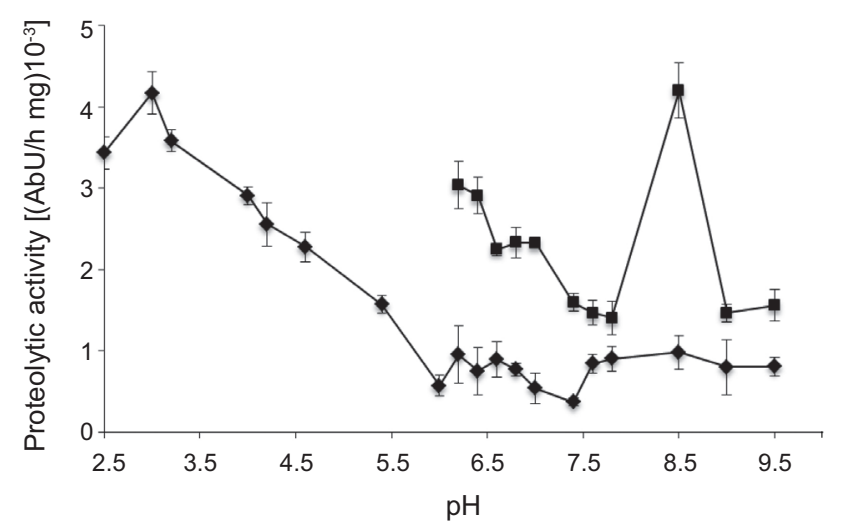

FIGURE 2. Effect of $\mathrm{pH}$ on the general proteolytic activity of salmon flesh; ( ) at $55^{\circ} \mathrm{C}$ and $(-)$ at $65^{\circ} \mathrm{C}$. stage of the study, the $\mathrm{pH}$ values at which endogenous enzymes have the maximum activity were determined. The results showed that acid, neutral and alkaline endogenous proteases of cod flesh had the optimal activity at $\mathrm{pH}$ 3.0, 7.4, and 8.5, respectively (Figure 1). Different values were demonstrated by Angsupanich \& Ledward [1998], who showed that the activity of endogenous proteases of cod (Gadus morhua) after 3 -h incubation at $55^{\circ} \mathrm{C}$ was the highest at $\mathrm{pH} 3.3,6.6$, and 9.0. In contrast, proteolytic enzymes of the flesh of Pacific cod (Gadus macrocephalus) after incubation at $50^{\circ} \mathrm{C}$ for 30 min were the most active at $\mathrm{pH} 3.2-3.6$ and 7.8-8.0 [Erickson et al., 1983].

The general proteolytic activity (GPA) of salmon flesh after 3-h incubation at $55^{\circ} \mathrm{C}$ was the highest in the acidic environment at $\mathrm{pH} 3.0$ (Figure 2). At this temperature and higher $\mathrm{pH}$ values, the enzymes demonstrated minimal activity. Stoknes \& Rustad [1995] showed that neutral and alkaline proteases of salmon flesh were more active at $65^{\circ} \mathrm{C}$ than at $55^{\circ} \mathrm{C}$. In this work, it has also been found that at the temperature of $65^{\circ} \mathrm{C}$ the neutral proteases exhibited the maximum activity at $\mathrm{pH}$ 7.0 whereas the alkaline ones at pH 8.5 (Figure 2).

Acidic proteases of beef meat, in contrast to the fish flesh enzymes, had the maximum activity at higher $\mathrm{pH}$ values ( $\mathrm{pH}$ 4.2). In turn, neutral and alkaline proteases were the most active at pH 6.2 and 7.8, respectively (Figure 3). For comparison, Ohmori et al. [1991] demonstrated that

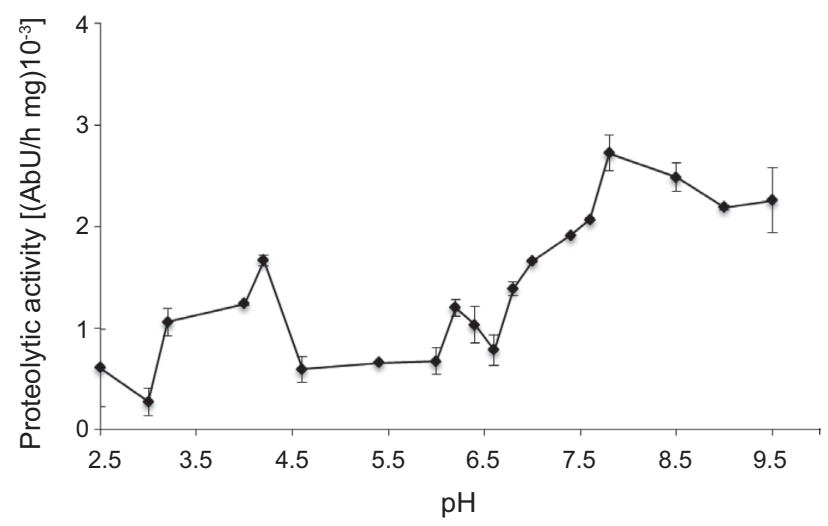

FIGURE 3. Effect of $\mathrm{pH}$ on the general proteolytic activity of beef meat.

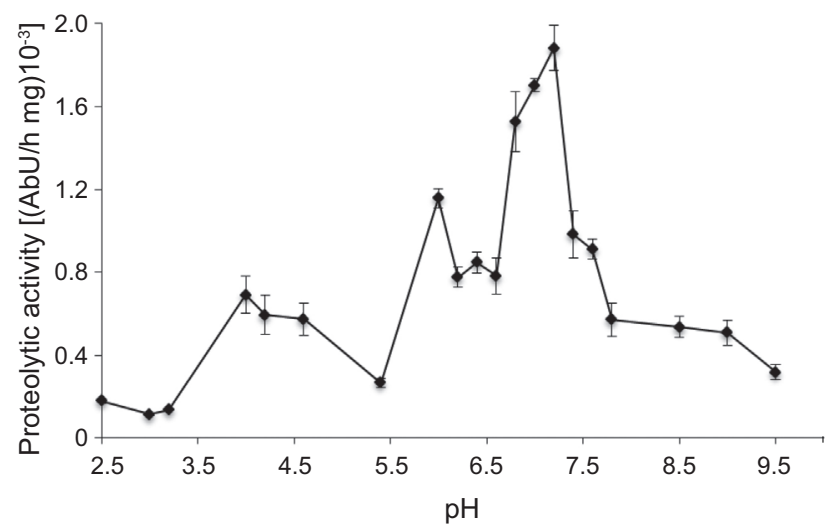

FIGURE 4. Effect of $\mathrm{pH}$ on the general proteolytic activity of pork meat. 
beef enzymes were the most active at $\mathrm{pH}$ 3.0, 7.0, and 8.0. The values obtained by these authors are similar to those presented in our study, and a small discrepancy may be due to differences in the parameters of the assay: 24-h incubation at $30^{\circ} \mathrm{C}$ and 3 -h incubation at $37^{\circ} \mathrm{C}$, respectively. In contrast to the beef proteolytic enzymes, the proteases of pork meat were active at $\mathrm{pH}$ 4.0, 6.0, and 7.0 (Figure 4). These data are consistent with the findings reported by García-Barientos et al. [2006].

\section{Effect of high pressure treatment on the activity of proteolytic enzymes}

Changes in the activity of endogenous proteolytic enzymes after pressurization were measured at the optimal $\mathrm{pHs}$ that were determined for enzymes from particular types of meat.

\section{Fish flesh}

It was stated that proteases from fish muscle are thought to be more pressure sensitive than those from mammals meat [Ashie \& Simpson, 1996] but Jantakoson et al. [2012] report- ed no change in protease activity in shrimp muscle after high pressure treatment up to $800 \mathrm{MPa}$ at $28^{\circ} \mathrm{C}$ for $30 \mathrm{~min}$. In our study, with increasing pressure in the range of 60-193 MPa at -5 to $-20^{\circ} \mathrm{C}$, respectively, the activity of acidic proteases of cod flesh did not change significantly, while the activity of neutral and alkaline proteases decreased 3 times (Figure 5A). Angsupanich \& Ledward [1998] also reported the lowering of the activity of neutral cod proteases after pressurization at $200 \mathrm{MPa}$ for $20 \mathrm{~min}$ at room temperature. However, the activity of acidic and alkaline proteases increased slightly under these conditions, but decreased at higher pressures of 400-800 MPa. In the case of enzymes of the flesh of sea bass (Dicentrarchus labrax L.), calpains (neutral and alkaline proteases) completely retained their activity after pressurization at $100 \mathrm{MPa}$, but at $300 \mathrm{MPa}$ they were inactivated. The loss of calpains activity at high pressure was due to structural modifications and dissociation of the heterodimeric form of the protein [Cheret et al., 2007b], while Homma et al. [1995] suggested the possibility of autolysis. The decreased calpain activity possibly prevents degradation of myofibrillar
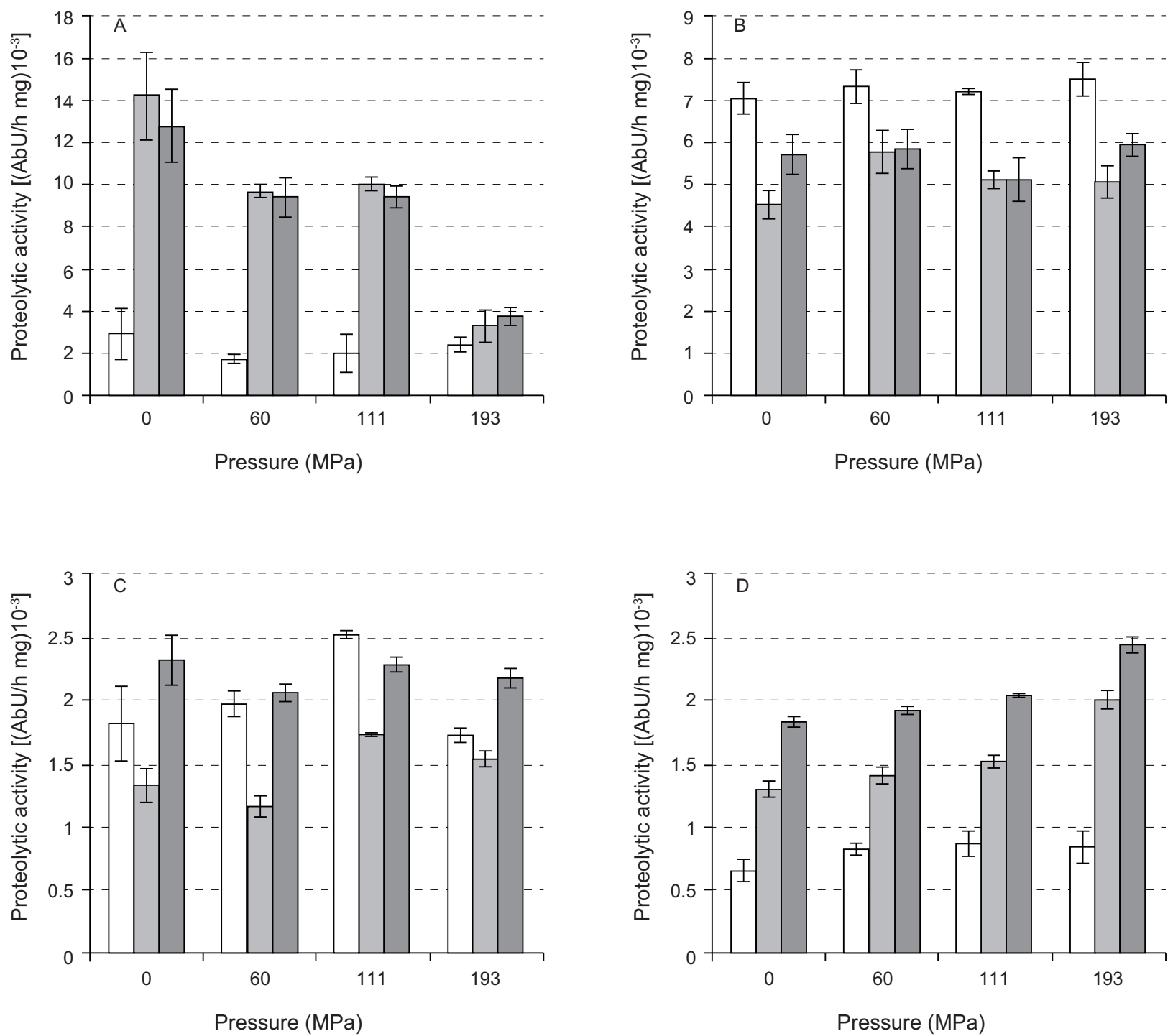

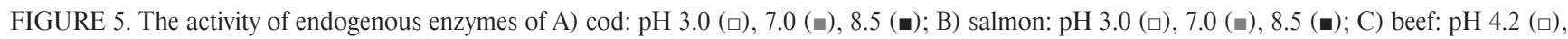
$6.2(\varpi), 7.8(\bullet) ;$ D) pork: $\mathrm{pH} 4.0(\square), 6.0(\square), 7.0(\bullet)$ meat after pressure treatment at subzero temperature. 
fish proteins under high pressure. Such a possibility was highlighted in the review article of Campus [2010] and in a work by Duranton et al. [2014].

Proteolytic enzymes of salmon flesh were more resistant to pressures in the range from 60 to $193 \mathrm{MPa}$ at the temperature from -5 to $-20^{\circ} \mathrm{C}$ than cod enzymes (Figure $5 \mathrm{~B}$ ). The activity of acidic and alkaline proteases did not change after pressure treatment at 60-193 MPa, whereas the activity of neutral proteases increased after pressurization of $60 \mathrm{MPa}$. At the higher pressure (above $60 \mathrm{MPa}$ ) these enzymes activity decreased to the value noted in the untreated control samples. Higher pressure-resistance of proteolytic salmon enzymes compared to cod enzymes may be due to the protective effect of lipids. Salmon flesh contains about 7\%, and cod flesh only $0.5-1 \%$ of lipids [Łuczyńska et al., 2014; Zeng et al., 2010]. In the available literature, there is no data on the activity of proteases in salmon flesh as affected by pressure treatment. Only Lakshmanan et al. [2005] have shown that the activity of the endogenous protease of cold-smoked salmon flesh at $\mathrm{pH} 6.0$ decreased after pressure treatment at $150 \mathrm{MPa}$ and $9^{\circ} \mathrm{C}$, and then increased at 200 and $300 \mathrm{MPa}$ to the level as in the unpressurized sample. In this range of pressure, the activity of proteolytic enzymes at $\mathrm{pH} 6.5$ did not change significantly. A similar phenomenon was observed in the case of cathepsin D in Atlantic horse mackerel, the activity of which increased about 2-fold after pressurization at $300 \mathrm{MPa}$ for $5 \mathrm{~min}$, while $450 \mathrm{MPa}$ treatment provoked a decrease in its activity to the same value as in the unpressurized sample [Fidalgo et al., 2014].

\section{Mammals meat}

The activity of the endogenous enzymes of bovine meat, except at $7.8 \mathrm{pH}$, increased by about $25 \%$ after pressurization at $111 \mathrm{MPa}$ and $-10^{\circ} \mathrm{C}$ (Figure $4 \mathrm{C}$ ). However, after the treatment at $193 \mathrm{MPa}$ their activity decreased to the level similar to that in the unpressurized meat. Ohmori et al. [1991] have shown that the activity of the acidic, neutral, and alkaline proteases of bovine meat did not change even after pressure treatment of $400 \mathrm{MPa}$ at room temperature. The increase of cathepsins B, D and L activity after pressurization up to $400 \mathrm{MPa}$ was also observed in beef meat [Homma et al., 1994]. However, Koohmaraie et al. [1984] and Homma et al. [1995] observed the decreased calpain activity in pressurized beef $\left(100 \mathrm{MPa}, 37^{\circ} \mathrm{C}, 2 \mathrm{~min}\right)$ and rabbit meat $\left(200 \mathrm{MPa}, 2^{\circ} \mathrm{C}\right.$, $5 \mathrm{~min})$, respectively. Almost complete inactivation was observed at $400 \mathrm{MPa}$ [Homma et al. 1995], which was related to the lower distribution of calpains in pressurized beef muscle, as observed with the immunogold electron microscopy [Borjigin et al., 2006].

Next, endogenous acidic and neutral proteases of porcine meat (with optimal activities at pH 6.0 and 7.0, respectively) were activated by high-pressure treatment (Figure 4D). Their activity increased by 66 and 36\%, respectively, with pressure increase up to $193 \mathrm{MPa}$. Some authors have pointed out that the activation of neutral and alkaline proteases (calpains) in pressurized meat may be induced by an increasing concentration of calcium in the cytosol as a result of disruption of the endoplasmic reticulum and mitochondria [Cheret et al., 2007a]. In contrast, Grossi et al. [2012]
TABLE 1. Activity of endogenous TGase of cod and salmon flesh after pressurization at 60 and $193 \mathrm{MPa}$.

\begin{tabular}{l|c|c}
\hline \multirow{2}{*}{$\begin{array}{l}\text { Pressure } \\
(\mathrm{MPa})\end{array}$} & \multicolumn{2}{|c}{$\begin{array}{c}\text { Activity of endogenous TGase } \\
(\mathrm{U} / \mathrm{mg} \text { proteins })\end{array}$} \\
\cline { 2 - 3 } & Salmon flesh & Cod flesh \\
\hline 0.0 & $0.417 \pm 0.028^{\mathrm{a}}$ & $2.136 \pm 0.094^{\mathrm{a}}$ \\
60 & $0.353 \pm 0.015^{\mathrm{b}}$ & $\mathrm{Nd}^{\mathrm{b}}$ \\
193 & $0.328 \pm 0.078^{\mathrm{b}}$ & $\mathrm{Nd}^{\mathrm{b}}$ \\
\hline
\end{tabular}

Nd. - not detected; a, b - values for a particular column followed by different letters differ significantly $(\mathrm{p}<0.05)$ (mean $\pm \mathrm{SD}, \mathrm{n}=6$ ).

showed that the activity of $\mu$-calpain in fresh porcine longissimus muscle decreased by 15 and $80 \%$ after pressurization at 50 and $100 \mathrm{MPa}$, respectively. However, m-calpains activity was almost unaffected under these conditions. Complete inactivation of both $\mathrm{m}$ - and $\mu$-calpain was achieved at $200 \mathrm{MPa}$ [Grossi et al., 2012].

In the case of acidic proteases ( $\mathrm{pH} 4.0$ ) of pork meat, the increase of pressure caused only $28 \%$ increase in their activity. This may be due to the release of acidic proteases to the cytosol as a result of disintegration/modification of the lysosomal membranes [Jung et al., 2000; Kubo et al., 2002; Duranton et al., 2014]. In the available literature there is lack of data on the effect of pressure treatment on the endogenous enzymes of raw porcine meat. However, Campus et al. [2008] showed that activities of cathepsin $\mathrm{B}$ and $\mathrm{B}+\mathrm{L}$ of dry-cured pork loins were not affected significantly at 300 and $350 \mathrm{MPa}$ while at $400 \mathrm{MPa}$ there was a decrease of around $20 \%$ of their initial activity. In contrast, increasing activity of cathepsins B and $\mathrm{L}$ in brine-enhanced semitendinosus has been noticed after pressurization at $600 \mathrm{MPa}$ [Grossi et al., 2012].

\section{Effect of high pressure treatment on transglutaminase activity}

TGase isolated from various organisms differs in the optimum $\mathrm{pH}$ at which it exhibits the maximum activity. In oysters meat (Crassostrea gigas), this enzyme shows the maximum activity at pH 8.0 [Kumazawa et al., 1997], while in tilapia flesh (Oreochromis niloticus) at pH 7.0-7.5 [Worratao et al., 2005]. The optimal temperature ensuring the maximum activity of the enzyme also depends on its origin. TGase from carp and bream flesh is the most active at $50^{\circ} \mathrm{C}$, whereas that from the flesh of threadfin breams (Nemipterus virgatus) and white croaker (Genyonemus lineatus) - at 40 and $30^{\circ} \mathrm{C}$, respectively [Tsukamasa et al., 2002]. These authors showed also that TGase from different sources retained at least $80 \%$ of its maximum activity at $37^{\circ} \mathrm{C}$. Therefore, in our study TGase activity in cod and salmon flesh was measured at this temperature. It has been shown that the activity of this enzyme in cod was 5 times higher than in salmon (Table 1).

Depending on the type of meat, these enzymes are also significantly different in sensitivity to pressure. The pressure treatment at 60 and $193 \mathrm{MPa}$ led to complete inactivation of TGase in cod flesh, whereas the activity of salmon flesh TGase was decreased by only 15 and $21 \%$, respectively (Table 1). Montero et al. [2005] have also shown that the activity of TGase from horse meat (Trachurus trachurus) subjected 
to a pressure treatment at $300 \mathrm{MPa}$ and $25^{\circ} \mathrm{C}$ for $15 \mathrm{~min}$ decreased by $35 \%$. Zhou et al. [2013] demonstrated inactivation of threadfin bream (Nemipterus bleekeri) TGase as a result of the decrease of $\varepsilon$-( $\gamma$-glutamyl) lysine linkage formation. In contrast, endogenous TGase of Alaska pollock (Theragra chalcogramma) flesh and microbial TGase added to surimi were resistant to 15-min pressure treatment in the range 100$-300 \mathrm{MPa}$ at $4^{\circ} \mathrm{C}$ [Ashie \& Lanier, 1999], which indicates that this enzyme has different pressure sensitivity depending on its origin.

\section{CONCLUSIONS}

The high pressure treatment at subzero temperature causes a number of changes in the components of the muscle tissue of fish and mammals [Malinowska-Pańczyk et al., 2014]. Some of them, e.g. inducing gelation of proteins, may be used in the food industry for designing new products with improved functional and sensory properties, while others limit the use of this technique. The present study has demonstrated high pressure effects on the activity of proteolytic enzymes of fish flesh and mammals meat. Pressurization can be useful in reducing the softening of fish flesh because it decreases the activity of neutral and alkaline proteases of cod flesh. By contrast, the exposure of mammals meat to high pressure of $193 \mathrm{MPa}$ at $-20^{\circ} \mathrm{C}$ may enhance the endogenous proteases participating in meat tenderization. Moreover, such phenomena may coincide with the inactivation of microorganisms, since the pressure of $193 \mathrm{MPa}$ leads to a reduction in the number of meat spoilage microflora [MalinowskaPańczyk \& Kołodziejska, 2013].

\section{RESEARCH FUNDING}

This study was financed by the national research budget provided for the years 2007-2010.

\section{ACKNOWLEDGEMENTS}

The authors also wish to express their gratitude to Professor Zdzisław E. Sikorski for his help in preparing this manuscript for publication.

\section{CONFLICT OF INTERESTS}

Authors declare no conflict of interests.

\section{REFERENCES}

1. Ahmed Z., Donkor O., Street W.A., Vasiljevic T., Calpainsand cathepsins-induced myofibrillar changes in post mortem fish: Impact on structural softening and release of bioactive peptides. Trends Food Sci. Technol., 2015, 45, 130-146.

2. Angsupanich K., Ledward D.A., High pressure treatment effects on cod (Gadus morhua) muscle. Food Chem., 1998, 63, 39-50.

3. Ashie I.N.A. Simpson B.K., Application of high hydrostatic pressure to control enzyme related fresh seafood texture deterioration. Food Res. Int., 1996, 29, 569-575.
4. Ashie I.N.A., Lanier T.C., High pressure effects on gelation of surimi and turkey breast muscle enhanced by microbial transglutaminase. J. Food Sci., 1999, 64, 704-708.

5. Borjigin G., Yamamoto S., Sugiyama T., Nishiumi T., Suzuki A., Changes in immunogold electron-microscopic localization of calpain in bovine skeletal muscle induced by conditioning and high-pressure treatment. Biosci. Biotechnol. Biochem., 2006, 70, 1249-1254.

6. Campus M., High pressure processing of meat, meat products and seafood. Food Eng. Rev., 2010, 2, 246-273.

7. Campus M., Flores M., Martinez A., Toldra F., Effect of high pressure treatment on colour, microbial and chemical characteristics of dry cured loin. Meat Sci., 2008, 80, 1174-1181.

8. Cheret R., Delbarre-Ladrat C., de Lamballerie-Anton M., Verrez-Bagnis V., High-pressure effects on the proteolytic enzymes of sea bass (Dicentrarchus labrax L.) fillets. J. Agric. Food Chem., 2005, 53, 3969-3973.

9. Cheret R., Delbarre-Ladrat C., de Lamballerie-Anton M., Verrez-Bagnis V., Calpain and cathepsin activities in post mortem fish and meat muscles. Food Chem., 2007a, 101, 1474-1479.

10. Cheret R., Delbarre-Ladrat C., Verrez-Bagnis V., de Lamballerie-Anton M., Effect of high pressure on the calpain-calpastatin system in fish muscle. J. Food Sci., 2007b, 72, C313-C316.

11. DeJong G.A.H., Koppelman S.J., Transglutaminase catalyzed reactions: impact on food applications. J. Food Sci., 2002, 67, 2798-2806.

12. Duranton F., Simonin H., Guyon C., Jung S., de Lamballerie M., High-pressure processing of meats and seafood. 2014, in: Emerging Technologies and Food Processing (ed. D.W. Sun). Elsevier Science, pp. 35-63.

13. Erickson M.C., Gordon D.T., Anglmier A.F., Proteolytic activity in sarcoplasmatic fluids of parasitized Pacific Whiting (Merluccius productus) and unparasitized True cod (Gadus macrocephalus). J. Food Sci., 1983, 48, 1315-1319.

14. Esposito C., Caputo I., Mammalian transglutaminases. Identification of substrates as a key to physiological function and physiopathological relevance. FEBS J., 2005, 272, 615-631.

15. Fidalgo L.G., Saraiva J.A., Aubourg S.P., Vazquez M., Torres J.A., High pressure effects on the activities of cathepsins B and D of Mackerel and Horse Mackerel muscle. Czech J. Food Sci., 2014, 32, 188-193.

16. García-Barientos R., Perez Chabela M.L., Montejano J.G., Guerrero Legarreta I., Changes in pork and shark (Rhizopriondon terraenovae) protein emulsions due to exogenous and endogenous proteolytic activity. Food Res. Int., 2006, 39, 1012-1022.

17. Grossi A., Gkarane V., Otte J.A., Ertbjerg P., Orlien V., High pressure treatment of brine enhanced pork affects endopeptidase activity, protein solubility, and peptide formation. Food Chem., 2012, 134, 1556-1563.

18. Homma N., Ikeuchi Y., Suzuki A., Effect of high pressure treatment on the proteolytic enzymes in meat. Meat Sci., 1994, 38, 219-228.

19. Homma N., Ikeuchi Y., Suzuki A., Levels of calpain and calpastatin in meat subjected to high pressure. Meat Sci., 1995, 41, 251-260.

20. Jantakoson T., Kijroongrojana K., Benjakul S., Effect of high pressure and heat treatments on black tiger shrimp (Penacus monodon Fabricius) muscle protein. Int. Aquat. Res., 2012, 4, 19, 1-12. 
21. Jung S., de Lamballerie-Anton M., Taylor R.G., Ghoul M., High-pressure effects on lysosome integrity and lysosomal enzyme activity in bovine muscle. J. Agric. Food Chem., 2000, 48, 2467-2471.

22. Klomklao S., Benjakul S., Simpson B.K., Seafood Enzymes: Biochemical properties and their impact on quality. 2012, in: Food Biochemistry and Food Processing (ed. B.K. Simpson). Wiley-Blackwell, pp. 263-286.

23. Koohmaraie M., Kennick W.H., Elgasim E.A., Anglemeier A.F., Effect of pre rigor pressurization on the activity of calcium-activated factor. J. Food Sci., 1984, 40, 680-684.

24. Kubo T., Gerelt B., Han G.D., Sugiyama T., Nishiumi T., Suzuki A., Changes in immunoelectron microscopic localization of cathepsin D in muscle induced by conditioning or high-pressure treatment, Meat Sci., 2002, 61, 415-418.

25. Kumazawa Y., Sano K., Seguro K., Yasueda H., Nio N., Motoki M., Purification and characterization of transglutaminase from Japanese oyster (Crassostrea gigas). J. Agric. Food Chem., 1997, 45, 604-610.

26. Lakshmanan R., Patterson M.F., Piggott J.R., Effects of high-pressure processing on proteolytic enzymes and proteins in cold-smoked salmon during refrigerated storage. Food Chem., 2005, 90, 541-548.

27. Łuczyńska J., Paszczyk B., Łuczyński M.J., Fatty acid profiles in marine and freshwater fish from fish markets in northeastern Poland. Arch. Pol. Fish., 2014, 22, 181-188.

28. Malinowska-Pańczyk E., Kołodziejska I., The influence of moderate pressure and subzero temperature on the shelf life of minced cod, salmon, pork and beef meat. Food Technol. Biotechnol. 2013, 51, 570-576.

29. Malinowska-Pańczyk E., Walecka M., Pawłowicz R., Tylingo R., Kołodziejska I., The effect of high pressure at subzero temperature on proteins solubility, drip loss and texture of fish (cod and salmon) and mammal's (pork and beef) meat. Food Sci. Technol. Int., 2014, 20, 383-395.

30. Martysiak-Żurowska D., Puta M., Barczak N., Dąbrowska J., Malinowska-Pańczyk E., Kiełbratowska B., Kołodziejska I., Effect of high pressure and sub-zero temperature on total antioxidant capacity and the content of vitamin $\mathrm{C}$, fatty acids and secondary products of lipid oxidation in human milk. Pol. J. Food Nutr. Sci., 2017, 67, 117-122.

31. Montero P., Lopez-Caballero M.E., Perez-Mateos M., Solas M.T., Gomez-Guillen M.C., Transglutaminase activity in pres- sure-induced gelation assisted by prior setting. Food Chem., 2005, 90, 751-758.

32. Ohmori T., Shigehisa T., Taji S., Hayashi R., Biochemical effects of high hydrostatic pressure on the lysosome and proteases involved in it. Biosci. Biotechnol. Biochem., 1992, 56, 1285-1288.

33. Ohmori T., Shigehisa T., Taji S., Hayashi R., Effect of high pressure on the protease activities in meat. Agric. Biol. Chem., 1991, 55, 357-361.

34. Serafini-Fracassini D., Del Duca S., Tranglutaminases: wide-spread cross-linking enzymes in plants. Ann. Bot., 2008, 102, 145-152.

35. Stoknes I., Rustad T., Proteolytic activity in muscle from Atlantic Salmon (Salmo salar). J. Food Sci., 1995, 60, 711-714.

36. Stoknes I.S., Walde P.M., Synnes M., Proteolytic activity in cod (Gadus morhua) muscle during salt curing. Food Res. Int., 2005, 38, 693-699.

37. Tokuşoğlu Ö., Effect of high hydrostatic pressure processing strategies on retention of antioxidant phenolic bioactives in foods and beverages - a review. Pol. J. Food Nutr. Sci., 2016, 66, 243-251.

38. Toldra F., Reig M., Enzymes in meat and fish. 2015, in: Improving and Tailoring Enzymes for Food Quality and Functionality (ed. R. Yada). Elsevier Ltd., pp. 199-212.

39. Truong B.Q., Buckow R., Stathopoulos C.E., Nguyen M.H., Advances in high-pressure processing of fish muscles. Food Eng. Rev., 2015, 7, 109-129.

40. Tsukamasa Y., Miyake Y., Ando M., Makinodan Y., Total activity of transglutaminase at various temperatures in several fish meats. Fish Sci., 2002, 68, 929-933.

41. Wasson D.H., Fish muscle proteases and heat-induced myofibrillar degradation: a review. J. Aq. Food Prod. Tech., 1992, 1, 23-41.

42. Worratao A., Yongsawatdigul J., Purification and characterization of transglutaminase from tropical tilapia (Oreochromis niloticus). Food Chem., 2005, 93, 651-658.

43. Zeng D., Mai K., Ai Q., Milley J.E., Lall S.P., Lipid and fatty acid compositions of cod (Gadus morhua), haddock (Melanogrammus aeglefinus) and halibut (Hippoglossus hippoglossus). J. Ocean Univ. China, 2010, 9, 381-388.

44. Zhou A.-M., Lin L.-Y., Liang Y., Zhang F., Yang H., Liu X., Chen Y.-Q., Gelling properties of the surimi induced by ultrahigh pressure. Modern Food Sci. Technol., 2013, 29, 2058-2062.

Submitted: 14 November 2016. Revised: 20 March and 5 May 2017. Accepted: 17 May 2017. Published on-line: 13 September 2017. 